\title{
特集に寄せて
}

\author{
常任理事・編集委員会委員長 碓水 光男 *
}

\section{Introduction to the Special Edition}

\author{
Mitsuo USUI*
}

\footnotetext{
* 日本電信電話株式会社 NTT デバイスイノベーションセンタ（† 243-0198＼cjkstart神奈川県厚木市森の里若宮 3-1）

* NTT Device Innovation Center, NTT Corporation (3-1, Morinosato Wakamiya, Atsugi, Kanagawa 243-0198)
}

エレクトロニクス実装学会誌 9 月号は, 毎年編集委員会 の企画による小特集を組むことになっています。各技術委 員会に依頼して企画していただく特集とは少し視点を変え て，より広い分野を俯㒈するような企画を目指したテーマ 設定を心がけております。

そこで，今回は会員の皆さまに興味を持っていただける 技術として，巻頭言でも触れましたが「ウェアラブルデバ イス技術」をテーマとして設定し，特集を組むことにしま した。

生活の中で身近な存在となりつつある「ウェアラブルデバ イス」について, その概念や構成, 期待される市場規模な どとともに，実際に開発が進むデバイスの実例，実装技術， デバイス間を接続する通信技術など，広範囲にわたりその 分野の第一人者に解説していただくことを目指し, 企画を 進めた結果，9件の解説記事を集めることができました。

まず，最初にウェアラブルデバイス全体の概念を理解し ていただくため, ウェアラブル環境情報ネット推進機構・ 板生 清氏, WIN フロンティア・駒澤真人氏に解説を依頼 しました。ウェアラブルを「情報ウェアラブル」と「環境 ウェアラブル」の 2 つ概念に分類し, その具体的な事例 をご紹介いただくとともに，近未来のウェアラブルデバイ スの展開についての解説をいただきます。

次に, ウェアラブルデバイスの市場規模と今後の展開に ついて, 矢野経済研究所・賀川勝氏に解説を依頼しまし た。具体的な製品例を示し, その課題・問題点とともに国 内および世界的な市場規模について，コンサルティングの 立場から解説をいただきます。

続いて, ウェアラブルデバイスの具体的な製品例とし て, 手首に装着する腕時計型デバイスの基板実装技術, セ ンサ技術およびその応用例について，セイコーエプソン・ 今井英生氏に解説をいただきます。

また， ウェアラブルデバイスで重要となる機器間のデー
夕通信技術のひとつとして注目される人体を伝送路として 利用する通信技術については 2 件, 東京工芸大学・越地福 朗氏, 青山学院大学・加藤康男氏に解説をいただきます。

さらに，医療・ヘルスケアなどへの応用としてのウェア ラブルデバイスの実例を 4 件ご紹介していきます。まず, 群馬大学・井上雅博氏, 多田泰徳氏には, 布地（テキスタ イル）を基板材料としたウェアラブルデバイスの材料, 回 路形成法, 課題などについて解説をいただきます。続いて, NTT ・桑原 啓氏, 高河原和彦氏には, 機能素材「hitoe」 を用いた着るだけで生体情報を計測できるウェアと，レー ザを用いた超小型血流センサについて解説をいただきま す。また，大阪府立大学・竹井邦晴氏には，印刷技術によ るフレキシブルセンサシートについて, ウェアラブル健康 管理デバイスに着目した応用例の解説をいただきます。そ して，兵庫県立大学・前中一介氏には，直接生体に貼り付 けるタイプのデバイスの現状と課題, 将来の姿について解 説をいただきます。

編集委員会一同, 今回の特集が会員の皆さまにとって, 今後の研究開発に役立つものであることを願っております。 最後に，ご多忙極まる中にもかかわらず，快くご執筆を 引き受けてくださった著者の皆さま，および今回の特集に あたり企画，編集に携わっていただいた関係者の方々に深 く感謝いたします。

(2015.8.14- 受理)

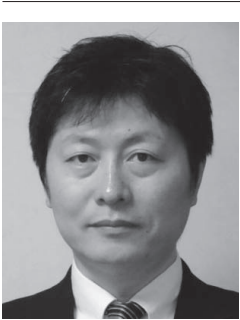

碓永光男 (うすい みつお)

著者紹介

1990 年東京電機大学大学院修士課程修了。同年日 本電信電話株式会社 (NTT) 入社。以来, 光インタ コネクション，有機光導波路，多心光コネク夕， MEMS ミラーデバイス, シリコンフォトニクスな ぞの実装技術に関する研究開発に従事。現在, NTTデバイスイノベーションセンタ所属。2015 年 度より本会常任理事・編集委員会委員長。 